\title{
Volatilisation of Heavy Metals from a Refuse Dump
}

\section{Lodenius, M.}

Elsevier Science Publishers B.V.

1986

Lodenius, M. and Braunschweiler, H. 1986. Volatilisation of Heavy Metals from a Refuse

Dump. The Science of the Total Environment 57: 253-255

http://hdl.handle.net/1975/203

Downloaded from Helda, University of Helsinki institutional repository.

This is an electronic reprint of the original article.

This reprint may differ from the original in pagination and typographic detail.

Please cite the original version. 


\title{
Short Communication
}

\section{VOLATILISATION OF HEAVY METALS FROM A REFUSE DUMP}

\author{
MARTIN LODENIUS and HANNU BRAUNSCHWEILER \\ Department of Environmental Science, University of Helsinki, SF-00710 Helsinki (Finland) \\ (Received February 20th, 1986; accepted March 3rd, 1986)
}

The medium-size refuse dump of Iso-Huopalahti in Helsinki on the shore of the Gulf of Finland was in use between 1963 and 1979. The amount of refuse dumped has been estimated to be 3.5 million $\mathrm{m}^{3}$ in an area of about $40 \mathrm{ha}$. The dump has mainly been used for municipal refuse, but some industrial wastes and toxic chemicals have probably also been dumped. The municipal refuse has included $\mathrm{Hg}$ and $\mathrm{Cd}$ batteries, fluorescent tubes, broken thermometers, etc. Incineration of this refuse has been shown to cause considerable emissions of heavy metals into the air (Mäkinen and Lodenius, 1984). Municipal sludge and miscellaneous soils have been used to cover the dump. A grass and shrub vegetation has been established, but part of the dump still has no vegetation. Emanating gases are allowed to escape through ventilation tubes at different sites around the dump.

It was assumed that the dump had also received wastes containing considerable amounts of heavy metals and we have investigated the amounts of heavy metals in the air above the dump. As mercury is easily the most volatile, special attention was paid to this metal. The evaporation of metals was investigated in the summer of 1985 using the moss-bag technique (Mäkinen, 1977). Moss-bags were suspended at a height of 1-3 $\mathrm{m}$ above the ground at 26 sites. Control moss-bags were placed in an agricultural area in northern Helsinki. The metals were analyzed by cold vapour AAS $(\mathrm{Hg})$ or flame $\mathrm{AAS}(\mathrm{Fe}, \mathrm{Zn}, \mathrm{Cd}$ and $\mathrm{Cu})$. Mercury was analyzed from all sites, the other metals from six sites only.

The mean monthly mercury accumulation in the moss-bags was $0.020 \mathrm{mg} \mathrm{kg}^{-1}$, which is only slightly higher than in the control area (Table 1). There were no significant differences in the mercury accumulation between the different parts of the dump, not even in the two moss-bags placed in the top of ventilation tubes. A similar result was obtained for the other metals.

A comparison with results from other moss-bag studies shows that the results from Iso-Huopalahti are, in general, a little higher than the background values from unpolluted areas, but at the same level as measured earlier in city areas. Consequently, the refuse dump does not seem to enhance the metal concentrations in air to levels above normal values in urban areas. 


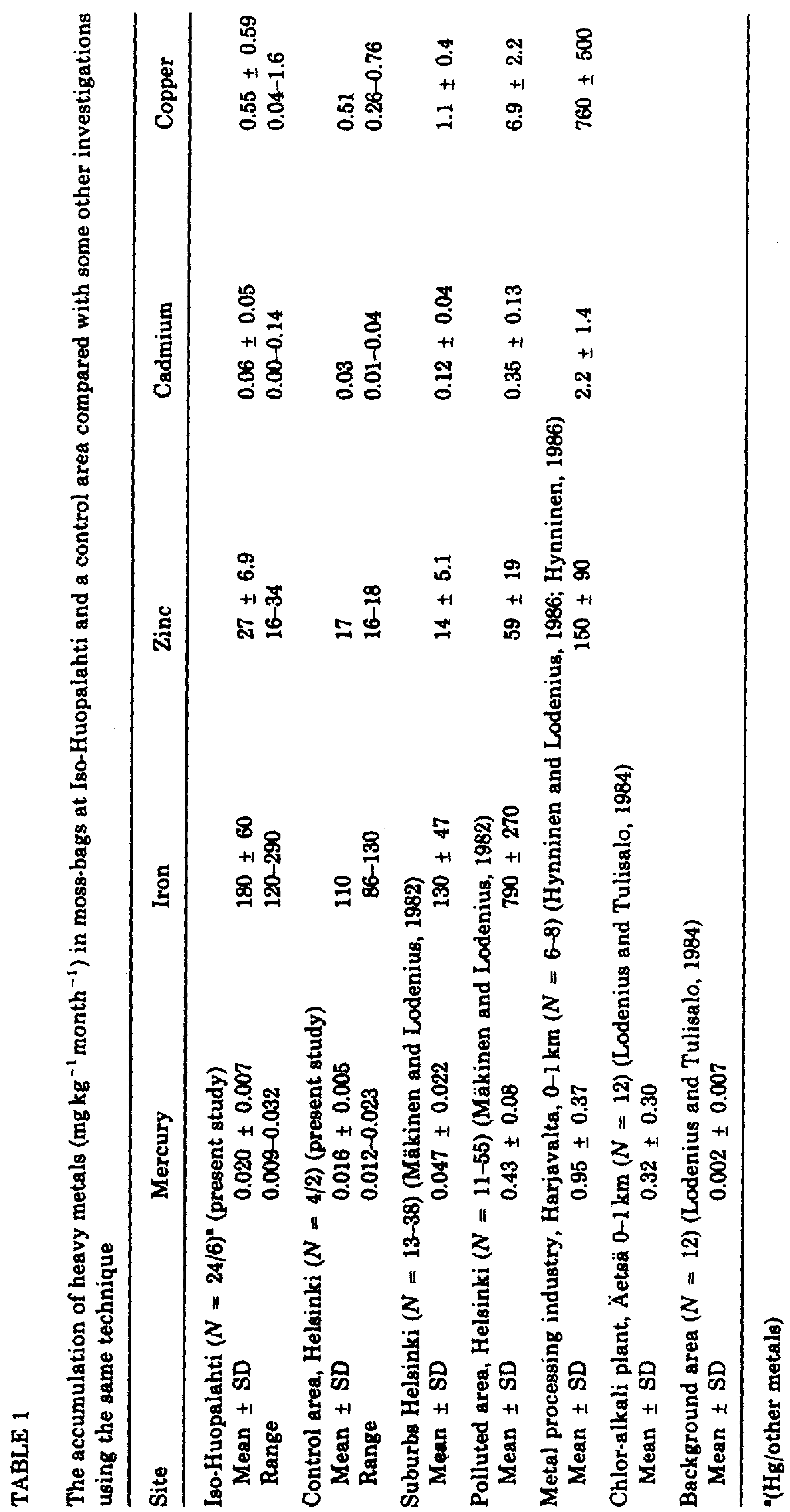




\section{REFERENCES}

Hynninen, V., 1986. Monitoring of airborne metal pollution with moss bags near an industrial Bource at Harjavalta, southwest Finland. Ann. Bot. Fenn., 23: 83-90.

Hynninen, V. and M. Lodenius, 1986. Mercury pollution near an industrial source in southwest Finland. Bull. Environ. Contam. Toxicol., 36: 294-298.

Lodenius, M. and E. Tulisalo, 1984. Environmental mercury contamination around a chlor-alkali plant. Bull. Environ. Contam. Toxicol., 32: 439-444.

Mäkinen, A., 1977. Summary: Moss- and peat-bags in air pollution monitoring. Suo, 28: 79-88.

Mäkinen, A. and M. Lodenius, 1982. Raskasmetallilaskeumat Helsingin itäisen kantakaupungin alueella syksyllä 1981. Helsingin kaupunki, jätehuoltokomitea, $193 \mathrm{s.}$

Mäkinen, A. and M. Lodenius, 1984. Summary: Urban levels of cadmium and mercury in Helsinki determined from moss-bags and feather mosses. Ympäristö ja Terveys, 15: 306-317. 